\title{
The Application of the Tagunta Learning Model in Elementary School 02 Lubuk Buaya, Padang
}

\begin{abstract}
Yuliasma ${ }^{1, *}$
${ }^{1}$ Faculty of Language and Arts, State University of Padang

*Corresponding Author.E-mail : yolyole63@gmail.co

ABSTRACT

Around $90 \%$ of primary schools in Koto Tangah District do not teach dance in class, start from grade I to grade VI. Many schools teach the dance lesson but in an extracurricular form. According to the observations of the researchers, the ignorance happened caused by the teachers do not understand the practical material which suitable for students, they also lack for knowledge and movement skills, and they have difficulty in choosing an effective dance learning model, so that they can improve students' ability to do expressive movements, creative and appreciative. The purpose of this research is to apply the TAGUNTA Learning Model as a learning model that can increase the effectiveness of dance learning in elementary schools. This research was included in the Quasi experiment and was carried out in the odd semester of the 2020/2021 school year. The data were collected through observation, and the students' dance learning outcomes test, then the data were analyzed by using the $T$ test. The results of analysis shows that the dance learning outcomes of students who are taught using the TAGUNTA learning model are higher than the dance learning outcomes of students who are taught using conventional learning models. The implication of this research is that the TAGUNTA learning model is effective for use in elementary schools, especially for grade III in elementary school.
\end{abstract}

\section{Keywords: Learning Model, TAGUNTA, Elementary School}

\section{INTRODUCTION}

Based on the preliminary study, the findings of researchers from 67 elementary schools in Koto Tangah District (57 public and 10 private SD) that carry out dance lessons in class, there are only 3 elentary schools, they are: SD Negeri 24 Parupuk Tabing, SD Negeri 15 Padang Sarai, and SD Negeri 11 Lubuk Buaya Padang. It means that $90 \%$ of elementary schools in Koto Tangah District do not teach dance in class, from grade I to grade VI. Many of schools do teach dance but in an extracurricular form. The neglect of dance learning in schools, according to the observations of researchers, teachers do not understand practical material that is suitable for students, they also lack adequate knowledge and movement skills, and they find the difficulties for choosing an effective dance learning model that can improve students' ability to do expressive movements, creative and appreciative. In addition, the most important thing is that there is no specific manual on how to teach dance for beginner students. As a result, teachers have difficulty teaching practice. If there is an activity that requires dancing, the school only hires the trainer for short period, for example when there are competitions between elementary schools, if there is no coach, the dance that is performed in entertainment at the school seems careless.

Based on the phenomena that the researchers found in the field as described above, it is very necessary to have a dance learning model that can help teachers transfer knowledge and dancing skills to students in elementary schools. The reality that has existed so far cannot be ignored because in particular it concerns the rights of students to get learning in the field of dance and it concerns the quality of education. Therefore, for the solution, the researchers applied the TAGUNTA learning model in elementary schools. The TAGUNTA learning model is one of the dance learning models that teachers can use in teaching dance in the form of practice.

Yuliasma,[1] conducted a research entitled "The TAGUNTA learning model in elementary schools". This TAGUNTA learning model is suitable for teacher to use based on the validity test by experts, for learning dance practice in class III SD. The TAGUNTA Learning Model requires creative teachers, especially in preparing learning experiences for students such as encouraging students creating to creative expressive movements. Expressive and creative movements are the main basis for learning dance as said by Craft.Anna [2], Koutsouba [3], Lorenzo-Lassa et.al [4] that creative movements contribute to the development of children's motor and expressive abilities, as well as the development of their creative intelligence. On the other hand, Torrance [5], Joyce [6], Pica [7] said that doing creative dance is the only activity where physical movement is used as a functional expression of the person that involves the mind, body and soul. Meanwhile, Craf. Anna [2]. emphasized that real art is related to creativity and important imagination and we 
must not forget to encourage children to create something art for themselves, whether through stories, rhythm, melody and choreography. Thus the TAGUNTA learning model stands for dance using stories. Stories are used to build students' imagination in producing explicit and creative movements as expressions of feelings so that learning becomes meaningful and enjoyable for students.

Students must be ready to take part in learning activities which in the implementation begin with warm-up movements, explore movements both individually and in groups, practice, work simple dances and display work in groups. In addition, students must have the courage to give an assessment of the results of group work. Craf. Anna [8] emphasized that real art is related to creativity and important imagination and we must not forget to encourage children to create something art for themselves, whether through stories, rhythm, melody and choreography. Thus, stories are a way to build students' imaginations in giving birth to specific movements as selfstatements.

The TAGUNTA learning model was developed from the results of previous research, namely the creative dance learning model, a study by Raquel Ros and Yannis Demiris [9] which produced three models namely; (a) general methodology; (b) sequence-based model; (c) concept based model. concept. The general methodology consists of the following stages: (1). Warm-up: the teacher starts the session with slow, smooth movements to stretch and strengthen the body. This stage gradually increases the dynamics of movement to really warm up the body; (2). Exploration, the teacher explains the concept of movement when students practice; (3) Creation and appreciation, individually or in groups, students make dance phrases or stages of motion sequentially. Then students provide an assessment of the results of group work. The TAGUNTA learning model is designed based on a general methodology model for learning creative dance developed by Raquel Ros, and composition theory developed by Jaqueline Smith [10]. Even in their research report, Lutz, $\mathrm{T}[11]$, stated that the process of learning music and creative dance can effectively save and preserve the distinctive cultural characteristics of traditional dance.

The specific objectives of this study are as follows: a) To identify the learning models used by teachers in teaching dance in elementary schools in Koto Tangah Padang. b). Implementing the effective TAGUNTA learning model in public elementary schools 02 Lubuk Buaya Padang.

The urgency of the research is if the objectives of this study are achieved, the TAGUNTA learning model becomes a reference for teachers and helps them to overcome the difficulties in learning dance, especially in the form of practice in elementary schools. The TAGUNTA learning model was able to motivate students to learn dance not only in offline learning systems (outside the network) or face to face. This learning model is thought to increase students' concentration in learning even though. It is in the form of online learning (online). In this case, of course, the teacher must be more confident in teaching so that students are active, creative and feel happy in participating in the learning process. The results of this study are imperative for teachers in changing the paradigm of dance learning, namely the first learning concept from "Learning to Dance is Difficult" to "Learning to Dance is Easy" secondly changing the teaching habits of the priestly system (Tradition), students imitating the movements of what the teacher does to become movements that are according to the wishes and needs of students (creative dance).

Initially the research was planned to use face-to-face learning systems or also called offline learning. However, the disaster that befell this nation with the global outbreak of the Covid-19 pandemic, the learning system has been changed to online learning (in the network). Changes that occur make teachers choose a communication tool via What's up apps because this application is considered easy for students to use in absorbing knowledge and skills.

Social media like What's up app is one of the most popular communication tools for humans in the world, including Indonesia. What's up app as a modern communication tool helps humans to get to know each other, interact via networks and various activities and information with other people without being face to face and getting to know each other over long distances. During this pandemic the What's up app plays a very important role in the development of education including the use of technology so that the use of the What's up app features in learning activities can improve learning outcomes and effectiveness. Likewise with this study in the learning process of the experimental class teacher and the control class teacher.Using the What's up app's communication tool as the only application that can help teachers in teaching in schools. Thus the application of the TAGUNTA learning model at SD Negeri 02 uses the group What's up app communication tool.

\section{RESEARCH METHODOLOGY}

This research is classified as a Quasi Experiment research, which is research that aims to obtain information that an estimate that can be obtained from the actual experiment, but in circumstances that do not allow to control the variables that can affect the dependent variable. The Quasi-experimental research belongs to the experimental research cluster.

The population of this study were all students of grade III SD Negeri Lubuk Buaya Padang who were registered in semester 1 of the 2020/2021 school year as many as 83 people while the research sample was class III b as many as 28 people as the control class and class IIIc as many as 28 people as the experimental class. The instrument of student dance learning outcomes is validated by three experts, namely linguists, dance learning experts and educational technology experts. To obtain test reliability results, an inter-assessor method was carried out, namely 2 (two) class teachers of SD Negeri 2 Lubuk Buaya Padang and 1 (one) student of dance skills in the FBS UNP Padang dance training course. Then the normality test and homogenous test were carried out. Furthermore, hypothesis testing is carried out using the $\mathrm{T}$ test. This is necessary to determine whether there is a significant effect 
for these two groups. If $\mathrm{T}$ count is greater than $\mathrm{T}$ table, it means that there is a difference between the TAGUNTA learning model and the conventional learning model.

\section{THE RESULT OF RESEARCH}

\section{a. Learning Model Analysis}

At this stage, the researchers collected information by observing learning at SD Negeri 02 Lubuk Buaya Padang, which was carried out online using the Wahtsaap application. This is a data on how teachers practice using more conventional learning models. Many students move carelessly, such as using poor energy, uncontrolled space for movement, and inappropriate timing or tempo of motion. Based on the results of interviews with low-grade teachers, it was found that they had a difficulty in teaching practice, among the teachers said, "While learning dance through offline / face-to-face, we have difficulty especially through online learning. They have not been able to complete the material related to basic skills skills. What they do, students are asked to imitate plant activities by providing information through voice notes in the What's up group. Then students are asked to practice the movements contained in the student book theme 2, sub theme 2 , lesson 1 about the dynamics of motion. The students are asked to imitate animal habits according to the chosen theme without doing movement stylization, things like this students cannot feel whether they are learning the art of dance or just imitating the movements of animal life or plant life. Thus, students' knowledge of the dynamics of movement associated with dance is far from the expectations and goals of learning.

The learning model using the What's up group communication tool actually provides the widest possible space for students to express themselves freely. However, students are not given explanations or instructions by the teacher on how to perform expressive dance movements, what objectives are to be achieved in relation to the objectives of learning dance. Students are not given the opportunity to find their personal movements. So that student activity is classified as very low because they imitate and do more movements in accordance with the wishes of their teachers and parents.

\section{b. The Application Steps of TAGUNTA Learning} Models

After analyzing the learning models used by the teacher in learning dance at SD Negeri 02 Lubuk Buaya Padang, the researchers concluded that the models used by teachers so far have not been able to improve students' abilities to produce expressive movements, because expressive motion is the first step in learn dance. If students are able foe creating the expressive movements as an expression of their feelings, then it is easy for them to learn to dance, and if students are not able to express expressive movements as self-expression, it is difficult for students to learn dance. Because the art of dance is an expression of the human soul that is expressed through rhythmic and beautiful movements Soedarsono,[12]. In connection with this problem, the researchers chose to apply the TAGUNTA learning model at SD Negeri02 Lubuk Buaya Padang, because this model has been scientifically tested from the results of Yuliasma's research in [1] which says that the TAGUNTA learning model is valid, practical and effective for use in elementary schools, especially for grade III SD.

The following describes the steps for implementing the TAGUNTA learning model and the conventional learning model in SD Negeri 02 Lubuk Buaya Padang. Histogram of Control Class and Experimental Class Learning Outcomes Test

1) Histogram of Control Class Learning Outcomes Test

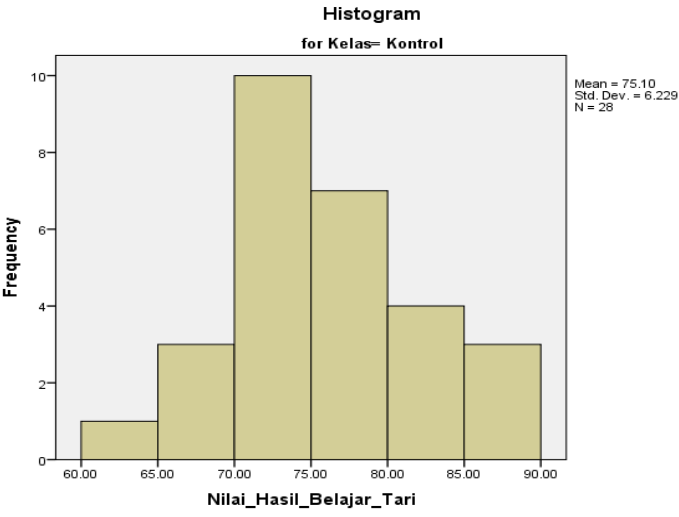

2) Histogram Test of Experimental Class learning outcomes

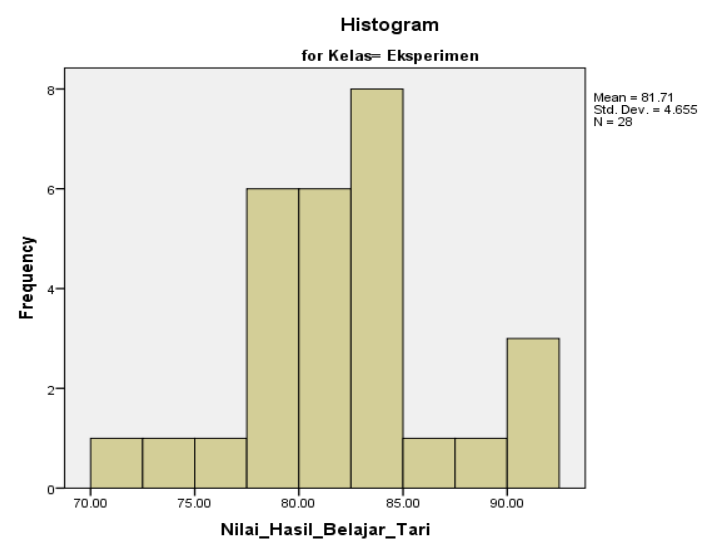

3) Testing Requirements Analysis

a) NORMALITY TEST

To see whether the population is normally distributed or not, the Liliefors test is used using the SPSS 20 program. The results of testing the learning outcomes of the experimental class and the control class show that both student dance learning outcomes are normally distributed $\therefore$ 0.200. $0.05=$ normal as below table and plot graph 

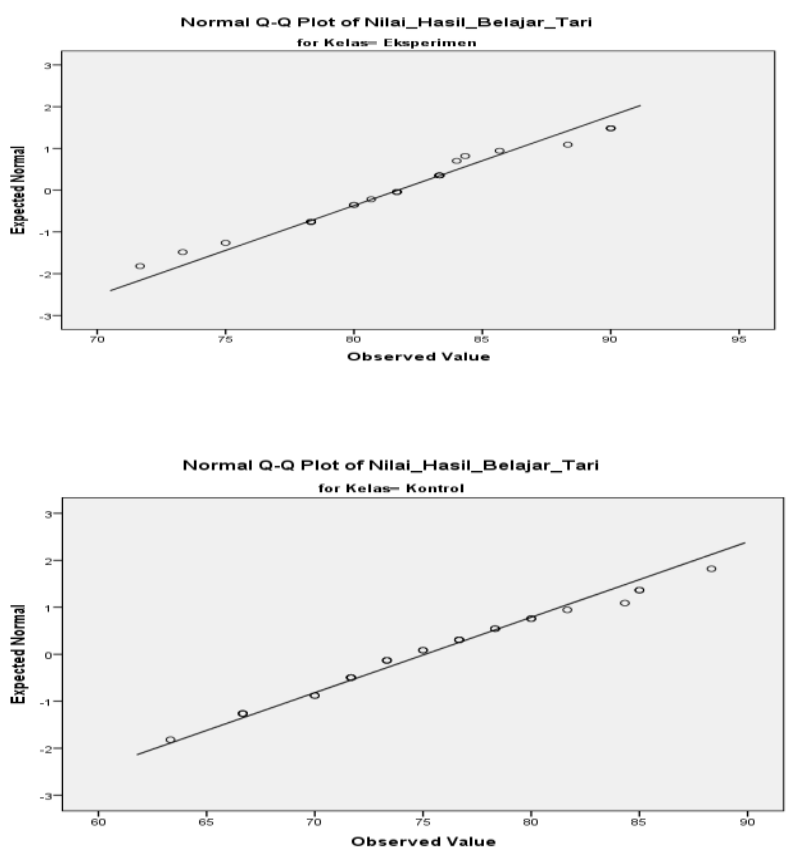

b) HOMOGENITY TEST

The homogeneity test was analyzed using the SPSS 20 program, the results of each research variable, namely the learning outcomes using the TAGUNTA learning model and the conventional learning model can be seen in the following table.

Tabel 1. Homogeneity test of learning outcomes in the experimental class and the control class

\begin{tabular}{|c|c|c|c|}
\hline $\begin{array}{l}\text { Levene } \\
\text { Statistic }\end{array}$ & df1 & df2 & Sig. \\
\hline 2.620 & 1 & 54 & 0.111 \\
\hline
\end{tabular}

The results of the homogeneity test in the experimental class and control class indicate that the data is homogeneous because the value of $0.111>0.05=$ homogeneous data.

\section{c) Hypothesis Test}

To test the hypothesis in this study, the T-test technique was used. From the results of hypothesis testing, it can be seen in the following table:

Table 2. Hypotesis Test

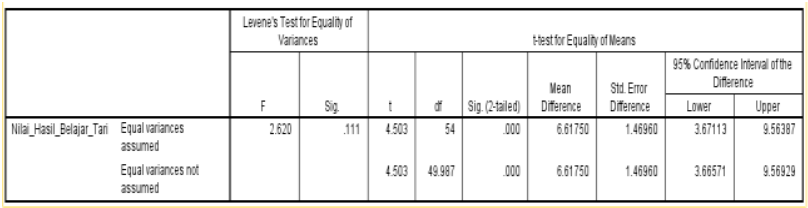

The $\mathrm{T}$ score obtained count $=4.503 \mathrm{t}$ table $=$ 1.67356 at a significance level of 0.05 . Because $t$ count $>t$ table, the null hypothesis (Hi) which says that the results of learning to dance students who are taught using the TAGUNTA learning model are the same as the learning outcomes of students taught using conventional learning models are rejected. This means that the research
Table 3. learning result

\begin{tabular}{|c|c|c|c|c|c|c|c|}
\hline & \multirow[t]{2}{*}{ Group } & \multicolumn{3}{|c|}{$\begin{array}{l}\text { Kolmogorov- } \\
\text { Smirnov }^{\mathrm{a}}\end{array}$} & \multicolumn{3}{|c|}{ Shapiro-Wilk } \\
\hline & & $\begin{array}{l}\text { Statis } \\
\text { tic }\end{array}$ & $\mathrm{df}$ & Sig. & $\begin{array}{l}\text { Statist } \\
\text { ic }\end{array}$ & df & $\begin{array}{l}\mathrm{Si} \\
\text { g. }\end{array}$ \\
\hline Learning & $\begin{array}{l}\text { Experim } \\
\text { ent }\end{array}$ & .127 & 28 & $.200^{*}$ & .955 & 28 & 8 \\
\hline & Control & .112 & 28 & $.200^{*}$ & .973 & 28 & 7 \\
\hline
\end{tabular}

*. This is a lower bound of the true significance.

a. Lilliefors Significance Correction

hypothesis (Hi) which says that the learning outcomes of the dancing group taught by using the TAGUNTA learning model are higher than the results of students' dancing learning taught using conventional learning models are accepted. Thus the TAGUNTA learning model is effectively used in dance learning at SD Negeri 02 Lubuk Buaya Padang.

\section{DISCUSSION}

The application of the TAGUNTA learning model in public elementary schools 02 Lubuk Buaya Padang is an effort by creative and innovative teachers who support students' dance learning in achieving learning objectives. The effectiveness of the application of the TAGUNTA learning model in the public elementary school 02 Lubuk Buaya Padang is carried out by providing an assessment of the learning outcomes of groups of students taught using the TAGUNTA learning model as a whole higher than the learning outcomes of student groups taught using conventional learning models. because the application of the TAGUNTA Learning Model in the experimental class shows a change in the behavior of students from those who do not know dancing to knowing, from those who cannot dance to being able, and from those who are not skilled in performing dance moves to becoming skilled. The freedom given in finding students' personal movements opens up a new discourse for students that dancing is not difficult, easy, fun and can be done by every student.

In addition, the problematic characteristics of this model are the teacher and the children create the stories that are connected to the themes that are available in SD and determine the activities contained in the story according to the plot. This is a unique activity and has not been found in other learning models. This strengthens the TAGUNTA learning model by choosing a contextual story theme that is related to the social life of the community (Lykesas , Tsapakidou, \& Tsompanaki,[13]. Like farming, fishing, gardening, batik, excursions, my cat and others. This activity will open opportunities for students to express their opinions in determining the content of the dance. The students can choose activities according to the theme. listening, seeing, responding to ideas can provoke students' creative imagination by exploring motion until they find motion. These learning experiences can help students in 
building positive behaviors such as; respect the opinion of friends, help friends in making motion to find motion which is the characteristic of this model, While the conventional learning model, learning activities are more dominated by teachers. Besides that, there are many benefits that students get after learning dance, the same thing was conveyed by Cheung [14]; Spanaki et al [15] Churcher[16], Sanderson,[17] state that there are many benefits for students when participating in dance lessons in elementary schools, such as: (a) developing and improving higher-order thinking skills; (b) develop kinesthetic intelligence; (c) communicate through rhythmic and beautiful movements; (d) cooperation, respect, (e) responsibility and discipline; (f) instill social values, mental and creative behavior.

The teacher asks students to imitate animal activities such as chickens, flying butterflies without manipulating motion. So that their ability to move is very limited, they cannot distinguish between strong, weak and moderate movements which are the key to material achievement, namely the dynamics of motion. Because they imitate more than find motion. Student books (textbooks) have not helped students much in producing expressive movements. The students' ability at this stage is to imitate and is very limited. So that students have not been able to distinguish between dance movements and daily movements. Students still feel shy in expression so that the movements made by students are almost the same as flapping their wings like imitating the motion of a chick.

Based on the description above, it can be concluded that the application of the TAGUNTA learning model is proven to improve student dance learning outcomes. This model can be used by teachers in dance learning, because the products produced from this model, namely student books and teacher books, it can help teachers and students absorb the knowledge and skills of dancing, especially for low grade students (class III), because many student book products display examples in the form of attractive pictures so as to motivate students to imitate, manipulate and discover dance movements.

The results of the analysis of variance, obtained $\mathrm{F}$ count $=$ .4 .503 and $F$ table 1.673 at the 0.05 significance level, because $\mathrm{F}$ count $>\mathrm{F}$ table, it can be concluded that there are differences in the dance learning outcomes of students who are taught using the TAGUNTA learning model which higher than the dance learning outcomes of students who use conventional learning models. Thus, the TAGUNTA learning model is effectively used in dance learning at public elementary school 02 Lubuk Buaya Padang.

\section{CONCLUSION}

The TAGUNTA learning model that has been implemented in public elementary schools 02 Lubuk Buaya Padang shows that student's dance learning outcomes are higher when compared to students' dance learning outcomes using conventional learning models. Thus, this model is easy to use and effective for achieving learning objectives, especially in teaching dance practices in grade III SD.

\section{IMPLICATION}

Based on the research results, there are several implications that can be raised, namely:

1. The findings show that the dance learning outcomes of students using the TAGUNTA learning model are higher than the dance learning outcomes of students using conventional learning models. It will gives an important implications for elementary school teachers, especially for grade III. The learning dance in the form of practice is more oriented towards developing students' abilities in creating to expressive movements as their self-statements. The teacher motivates students through stories to find motion as an expression of their feelings.

2. The results of this study have proven that the TAGUNTA learning model was a good model to be used in the implementation of dance learning in elementary school for grade III, because this model has been tested before. The test result proves that this model is very valid, practical, easy to use and effective in achieving learning objectives, especially for learning the practice of dance in grade III SD.

\section{REFERENCES}

[1] Yuliasma. 2019. Model Pembelajaran TAGUNTA di Sekolah Dasar. Disertasi : Padang. Pascasarjana Univeristas Negeri Padang

[2] Craf,Anna2004. Imajinasi \& Kreativitas Anak-Anak (Diterjemahkan oleh M Chairul A Anan). Depok: Cerdas Pustaka.

[3] Koutsouba, M. 2005. Notation of the Dancing Movement. From the Prehistory to the History of Dance. Athens: Propompos

[4] Lorenzo-Lasa, R., Ideishi, R. I., and Ideishi S. K. 2007. Facilitating Preschool Learning and Movement through Dance. Early Childhood Education Journal, Vol. 35, No. 1, Hlm. 25-31.

[5] Torrance, E. P. 1965. Rewarding Creative Behaviour: Experiments in Classroom Creativity. New Jersey: Prentice - Hall.

[6] Joyce, M. 1994. First Steps Teaching Creative Dance to Children. California: Mayfield Company

[7] Pica, R. 2004. Experiences in Movement: Birth to Age Eight (3rd ed.). Clifton, Park, NY: Thomson/Delmar Learning.

[8] Craft, Anna (2003). The limits to creativity in education: Dilemmas for the educator. BritishJournal of Educational Studies, 51(2), 113-127.

[9] Raquel Ros, Yiannis Demiris (2011). Creative Dance: an approach for Socia Interaction between Robots and Children. Imperial College London. SW7,2BT London. Uk

[10]Smith,Jacqueline.1985.KomposisiTari Sebuah Petunjuk Bagi Guru (Terjemahan Ben Suharto). Yogjakarta :Ekalasti 
[11] Lutz, T., and Kuhlman, W. D. 2000. Learning About Culture Through Dance inKindergartenClassrooms. Early Childhood Education Journal, Vol. 28, No. 1, Hlm. 35-40.

[12] Soedarsono. 1985. Peranan Seni Budaya dalam Sejarah Kehidupan Manusia Kontiunitas dan Perubahannya. Pidato pengukuhan Jabatan Guru Besar pada Fakultas Sastra Universitas Gadjah Mada Yogjakarta

[13] Lykesas, G., Tsapakidou, A. \& Tsompanaki, E. 2014. Creative Dance as a Means of Growth and Development of Fundamental Motor Skills for Children in First Grades of Primary Schools in

[14] Cheung, R. H. P. 2010. Designing Movement Activities to Develop Children's Creativity in Early Cchildhood Education. Early Child Development and Care, Vol. 180, No. 3, Hlm. 377-385.

[15] Spanaki, E., Skordilis, E., \& Venetsanou, F. 2010. The Effect of an Education Program in Kinetic Psychomotor Performance in School-Aged Children: First Inquiries in Physical Education \& Sport, Vol. 8, No. 2, Hlm. 132-141.

[16] Churcher, B. 1971. Physical Education for Teaching. London: George Allen and Unwin Ltd.

[17] Sanderson, P. 1988. Physical Education and Dance. Roberts T, ed., Encouraging Expression: The Arts in Primary School. London: Cassell 